\section{Price Elasticity of Demand for Beef and Range Improvement Decisions $^{1,2}$}

\section{JOHN P. WORKMAN, SAM L. KING 3 , AND JACK F. HOOPER}

Assistant Professor of Range Resource Economics and Graduate Student, Department of Range Science, Utah University, Logan; and Vice-President, Oppenheimer Industries, Kansas City, Mo.

\section{Highlight}

In recent years many leaders in the cattle industry have advocated restraint in cattle numbers in order to improve the cattleman's market position. During the same period, numerous articles have appeared in the Journal of Range Management recommending various range improvements as means of increasing beef output. There has been some question as to whether these two recommendations are contradictory. Since the rationality of the two recommendations depends upon the price elasticity of demand for beef, regression analysis was used to estimate a demand function for beef. An elasticity coefficient of $\mathbf{- 0 . 6 7}$ was derived from this function and then employed in the construction of a payoff matrix in order to determine the correct action for the individual rancher to take with regard to cattle numbers. The analysis indicates that increases in cattle numbers by individual ranchers (through range improvements or other management tools) are economically sound goals. The study also suggests that cattle numbers at the industry level will likely continue to increase despite the recommendations of cattle industry leaders.

Range researchers have traditionally been concerned with increasing livestock production on

${ }^{1}$ Received October 15, 1971.

2 The authors gratefully acknowledge reviews of the manuscript by colleagues Don D. Dwyer, Department of Range Science, and Darwin B. Nielsen, Department of Economics, Utah State University.

${ }^{3}$ Currently Game Biologist, Utah Division of Wildlife Resources, Salt Lake City. rangelands. Since beef is the most important meat in the United States (Working, 1954) great effort has been devoted to increasing cattle carrying capacity of the western range. According to Upchurch (1967), increasing the productivity of cattle ranges is an important concern because of the growing demand for beef and the expected increases in cattle numbers in the future. Numerous authors have recommended that various range improvement practices be implemented in order to increase rangeland cattle production (Cook and Jeferies, 1963; Hooper et al., 1969; Nielsen, 1967; Workman and Hooper, 1968).

Many leaders in the cattle industry, on the other hand, have recommended that the beef industry reduce the number of cattle marketed. They also recommend that cattlemen market their stock at lighter weights (American National Cattleman's Association, 1968a). Industry spokesmen observed that cattle prices have been below production costs since 1963 and expressed the belief that restraints in cattle numbers can restore the cattle industry to a sound position in the market. It was stated that "a one percent decrease in beef tonnage usually brings about a three to six percent increase in cattle prices." Gifford (1967) observed that beef cow numbers increased at the rate of $2 \%$ /year for the period 1957-1967. An annual increase in cattle numbers of $4.3 \%$ is possible for the period 1968 1972 (American National Cattleman's Association, $1968 \mathrm{~b})$ and the stated goal was to hold the growth rate down to 0.5 percent annually.

Thus, recommendations of the cattle industry and those of various range researchers appear to be contradictory. Both sets of recommendations are based on a concept of economics called "price elasticity of demand." The elasticity coefficient $(\mathrm{E})$ is defined as the percentage change in quantity sold of a product divided by the percentage change in 
price of the product (Leftwich, 1966). In algebraic terms

$$
\mathrm{E}=\frac{\Delta \mathrm{Q}}{\mathrm{Q}} \div \frac{\Delta \mathrm{P}}{\mathrm{P}} \text { or } \frac{\Delta \mathrm{Q}}{\Delta \mathrm{P}} \cdot \frac{\mathrm{P}}{\mathrm{Q}},
$$

where $\Delta$ denotes "change in." If the absolute value of $\mathrm{E}$ is greater than 1, price elasticity is said to be "relatively elastic" while if the absolute value of $\mathrm{E}$ is less than 1 , price elasticity is said to be "relatively inelastic." This concept states that as the quantity produced of any product is increased, price falls but, depending upon the nature of the demand curve for the product, total revenue (price multiplied by quantity sold) will increase (if demand is elastic) or will decrease (if demand is inelastic). In recommending that cattle production be increased through range improvement practices, range researchers have implicitly assumed an elastic demand for beef (that is, that the resultant decrease in beef price will be more than offset by the increase in pounds of beef produced). The industry recommendation discussed above is based on the assumption of an inelastic demand for beef (that the decrease in pounds sold will be more than offset by the increase in beef price).

Since published recommendations concerning cattle numbers appear to be contradictory and since such recommendations are based upon the concept of "elasticity of demand," a study was conducted to estimate the elasticity coefficient for beef. The elasticity coefficient was then used to test the economic rationality of recommendations suggesting (1) that ranchers decrease their cattle numbers in an attempt to force beef prices up and (2) that ranchers invest in range improvement programs designed to increase cattle numbers.

\section{Methods}

The quantity of beef purchased annually in the United States is a function of (1) the price of beef, (2) consumer income, (3) number of consumers, (4) price of substitute or complementary goods, and (5) the general price level (Working, 1927; Working, 1954; Liebhafsky, 1963). Data for the period 1947-1967 were obtained from Agricultural Statistics (1970). With the exception of beef substitutes and complements, each of the above independent variables was taken into account in a double natural logarithmic demand function which expressed per capita beef consumption (Q) as a function of deflated beef price $(\mathrm{P})$ and deflated disposal per capita income $(Y)$. In natural logarithms, the estimated demand function took the following form:

$$
\log Q=\log \mathrm{a}+\mathrm{b} \log \mathbf{P}+\mathrm{c} \log \mathrm{Y}
$$

Estimation of demand in terms of a double logarithmic function makes for ease of calculation of the elasticity coefficient (E). $E$ is the partial derivative of $\log Q$ with respect to $\log \mathrm{P}$ or simply $\mathrm{b}$.

A payoff matrix (Richmond, 1957) was used to predict the future trend in cattle numbers produced by the individual rancher and the resultant trend in cattle numbers at the industry level. The basic assumption upon which the model is based is that the rancher can control his own individual herd size but he has no control over cattle numbers at the industry level.

\section{Results and Discussion Elasticity of Demand}

Regression analysis of the data shown in Table 1 provided the following estimate of beef demand.

$$
\log Q=2.4259-0.6725 \log P+0.6012 \log Y
$$

where $Q=$ per capita beef consumption, $P=$ deflated price of choice beef, and $\mathrm{Y}=$ deflated disposable income per capita. The R-squared value was 0.97 and the $t$ values were significant at the 0.001 level for both $\mathrm{P}$ and $\mathrm{Y}$. The elasticity coefficient $(E)=d \log Q / d \log P=-0.6725$ which was rounded to -0.67 .

Several other estimates have been made of the elasticity of demand for beef. Working (1954) reported a relatively elastic demand of -1.1 for the period 1922-1941 while Learn (1956) estimated a relatively inelastic price elasticity of -0.73 for the years 1924-1954. Tomek (1965) reported an elasticity of -0.9 for the period 1956-1964. According to Breimeyer (1961) and Tomek (1965), price elasticities for meats have generally become more inelastic through time. Thus the somewhat more inelastic coefficient of -0.67 estimated in this study appears reasonable.

The price or elasticity coefficient indicates that the beef quantity consumed would decrease by 0.67 percent as a result of a one percent increase in price. The inverse of the price coefficient (sometimes referred to as the quantity coefficient)

$$
\frac{1}{-0.67}=-1.49
$$

shows the percent decrease in price which would result from a one percent increase in quantity. Thus, it was concluded that demand for beef in the United States for the period 1947-1967 was relatively inelastic and that at the present time any decrease in cattle numbers will result in more total revenue to the cattle industry as a whole since the increase in beef price will more than offset the decrease in quantity of beef sold. Thus the cattle industry recommendation for cattlemen to cut back on cattle numbers appears to be economically sound if the goal of the cattlemen is to increase total beef revenue at the industry level. ${ }^{4}$

${ }^{4}$ Economic analyses concerning elasticity of demand have
traditionally viewed maximum total revenue as the rele-
vant goal for management decisions. These analyses have
implicitly assumed that average costs remain constant as
supply is increased or decreased and that only average
revenue (price) changes with a change in output level.
Under these assumptions, total revenue is the relevant mea-
sure for decision making by the cattleman. However, it
should be recognized that as cattle numbers are decreased
on the individual ranch (in order to decrease industry wide
beef production as recommended by ANCA), the rancher
moves back along his average cost curve. Thus, in terms 
Table 1. Beef consumption per capita (lb.), price ( $\$$ cwt., choice), income (\$ billions), and population. ${ }^{1}$

\begin{tabular}{|c|c|c|c|c|c|c|c|c|}
\hline Year & $\begin{array}{c}(1) \\
\text { Beef } \\
\text { consumption }\end{array}$ & $\begin{array}{l}(2) \\
\text { Beef } \\
\text { price }\end{array}$ & $\begin{array}{c}(3) \\
\text { Consumer } \\
\text { price index } \\
1957-59=100 \\
\end{array}$ & $\begin{array}{c}(4) \\
\text { Disposable } \\
\text { personal } \\
\text { income }\end{array}$ & $\begin{array}{c}(5) \\
\text { Population } \\
(000,000) \\
\end{array}$ & $\begin{array}{c}(6) \\
\text { Disposable } \\
\text { income (\$)/ } \\
\text { capita } \\
(4) \div(5) \\
\end{array}$ & $\begin{array}{c}(7) \\
\text { Deflated } \\
\text { price of } \\
\text { beef }(\$) \\
(2) \div(3) \\
\end{array}$ & $\begin{array}{c}(8) \\
\text { Deflated } \\
\text { disposable } \\
\text { income (\$)/ } \\
\text { capita } \\
(6) \div(3) \\
\end{array}$ \\
\hline 1947 & 69.6 & 42.42 & 77.8 & 170.1 & 143.5 & 1185 & 54.52 & 1523 \\
\hline 1948 & 63.1 & 50.24 & 83.8 & 189.3 & 146.1 & 1296 & 59.95 & 1547 \\
\hline 1949 & 63.9 & 42.48 & 83.0 & 188.6 & 148.6 & 1270 & 51.18 & 1530 \\
\hline 1950 & 63.4 & 46.52 & 83.8 & 206.9 & 151.1 & 1369 & 55.51 & 1634 \\
\hline 1951 & 56.1 & 56.30 & 90.5 & 226.6 & 153.7 & 1474 & 62.21 & 1629 \\
\hline 1952 & 62.2 & 53.21 & 92.5 & 238.3 & 156.4 & 1523 & 57.52 & 1646 \\
\hline 1953 & 77.6 & 39.98 & 93.2 & 252.6 & 159.0 & 1589 & 42.90 & 1705 \\
\hline 1954 & 80.1 & 40.10 & 93.6 & 257.4 & 161.8 & 1591 & 42.84 & 1700 \\
\hline 1955 & 82.0 & 39.24 & 93.3 & 275.3 & 164.6 & 1672 & 42.06 & 1792 \\
\hline 1956 & 85.4 & 37.89 & 94.7 & 293.2 & 167.5 & 1750 & 40.01 & 1848 \\
\hline 1957 & 84.6 & 39.38 & 98.0 & 308.5 & 170.5 & 1809 & 40.18 & 1846 \\
\hline 1958 & 80.5 & 45.04 & 100.7 & 318.8 & 173.4 & 1839 & 44.73 & 1826 \\
\hline 1959 & 81.4 & 45.04 & 101.5 & 337.3 & 176.6 & 1910 & 44.57 & 1882 \\
\hline 1960 & 85.2 & 43.98 & 103.1 & 350.0 & 180.0 & 1944 & 42.66 & 1886 \\
\hline 1961 & 88.0 & 41.14 & 104.2 & 364.4 & 183.0 & 1991 & 39.48 & 1911 \\
\hline 1962 & 89.1 & 44.84 & 105.4 & 385.3 & 186.0 & 2071 & 42.54 & 1965 \\
\hline 1963 & 94.6 & 40.83 & 106.7 & 404.6 & 188.7 & 2144 & 38.27 & 2009 \\
\hline 1964 & 100.1 & 39.48 & 108.1 & 436.6 & 191.5 & 2280 & 36.52 & 2109 \\
\hline 1965 & 99.6 & 42.61 & 109.9 & 469.1 & 194.0 & 2418 & 38.77 & 2200 \\
\hline 1966 & 103.8 & 43.04 & 113.1 & 505.3 & 196.3 & 2574 & 38.67 & 2276 \\
\hline 1967 & 106.2 & 43.37 & 116.3 & 546.5 & 198.6 & 2752 & 37.29 & 2366 \\
\hline
\end{tabular}

1 Agricultural Statistics, 1970.

Future Trend in Cattle Numbers

The estimated elasticity of demand of -0.67 is of the magnitude for beef prices to increase in the event of a decrease in cattle numbers.

But is it likely that cattle numbers will actually be decreased in the future? A payoff matrix will be used to answer this question (Table 2). The payoff matrix model is composed of three possible trends in industry cattle numbers and three possible courses of action by the individual rancher. The three trends in cattle numbers at the industry level are:

Beef cattle numbers decrease by one percent.

Beef cattle numbers remain the same.

Beef cattle numbers increase by one percent.

These trends are on an industry wide basis and represent the total result of the actions of all individual ranchers. The individual rancher has no control over total beef cattle numbers. He operates in a purely competitive market in which his production is an insignificant portion of the total beef supply and he cannot influence beef price. He can sell all the beef he produces at the going price

of net revenue, the individual rancher may be better off or worse off after his total revenue has been increased due to the increase in beef price. The final effect on the net revenue of the individual cattleman depends upon (1) his original position on his average cost curve and (2) the shape of his average cost curve (whether relatively flat or steeply falling and rising). set in the industry wide market. The individual rancher does, however, control his own individual herd size. For illustrative purposes, it is assumed that the rancher can choose from among the following three courses of action:

Reduce his cattle numbers by one percent.

Leave his cattle numbers unchanged.

Increase his cattle numbers by one percent.

The outcomes shown in the matrix of Table 2 are in terms of the change in total revenue of the individual rancher. For instance, if beef cattle numbers decrease by one percent at the industry level and the rancher chooses to cooperate with the industry trend and decrease the size of his herd by one percent, his total revenue will increase by 0.48 percent. ${ }^{5}$

The final step in the use of the payoff matrix model is to choose the correct course of action for the rancher to follow, given the outcomes in Table 2 and the rancher's goal of maximum total revenue. Several formal criteria have been developed for making correct choices from among various courses of action (Spencer, 1968). However, even without

${ }^{5}$ Given our elasticity coefficient of -0.67 and the resultant quantity coefficient of -1.49 , a one percent decrease in beef quantity will cause price to increase by 1.49 percent. The increased beef price when multiplied times the decreased beef quantity gives a total revenue of: $101.49 \times$ $99=100.48$ or an increase in total revenue of 0.48 percent. 
Table 2. Payoff matrix showing nine possible changes (\%) in individual rancher total revenue.

\begin{tabular}{cccc}
\hline \hline $\begin{array}{c}\text { Change in } \\
\text { individual herd } \\
\text { size }(\%)\end{array}$ & \multicolumn{3}{c}{ Change in industry beef cattle numbers $(\%)$} \\
\cline { 2 - 4 } & \multicolumn{1}{c}{-1} & 0 & +1 \\
\hline-1 & +.48 & -1.00 & -2.48 \\
0 & +1.49 & 0 & -1.49 \\
+1 & +2.50 & +1.00 & -0.50 \\
\hline
\end{tabular}

applying formal criteria to the problem at hand, cursory examination of Table 2 indicates that no matter which of the three industry wide trends the rancher encounters, increasing his cattle numbers by one percent is the correct action to take. In each of the three cases, this action either maximizes the increase or minimizes the decrease in total revenue. It should be noted that the stronger the ranchers suspicion that the beef industry as a whole will reduce cattle numbers, the more likely that the rancher will increase his individual herd size. Of course, if each individual rancher expects the industry to decrease beef output, and each individual responds by increasing his herd, cattle numbers at the industry level will instead increase and each rancher will receive a decrease in total revenue. However, even in the event of industry wide increases in beef output, an increase in individual herd size is still the course of action which will minimize the individual rancher's revenue decrease.

It should be remembered that the payoff matrix (Table 2) was constructed using arbitrary annual changes in cattle numbers of one percent. Annual increases could be as high as two percent (as occurred between 1957 and 1967) but the relative relationships set out in Table 3 still apply. Of course, the greater the rate of increase in cattle numbers at the industry level, the greater the loss in total revenue of the individual rancher.

\section{Summary and Conclusions}

In recent years cattle industry leaders have advocated restraint in cattle numbers while many range researchers have recommended investment in range improvements in order to increase range carrying capacity and cattle numbers. There has been some question as to whether these recommendations are contradictory and, if so, what the correct strategy for range cattle operators really is. Since both recommendations are based on the price elasticity of demand for beef, regression analysis was employed to estimate a demand function for beef from which an elasticity coefficient of -0.67 was derived. According to this coefficient the demand for beef is said to be "relatively inelastic." This means that a given decrease in beef quantity will be more than compensated for by an increase in beef price, re- sulting in an increase in total beef revenue. Based on this coefficient, a payoff matrix was constructed which allowed the determination of the correct action for cattle ranchers to take regarding their herd sizes.

Although industry recommendations of restraint in cattle numbers is rational from the viewpoint of the cattle industry as a whole, the correct strategy for the individual cattle rancher to take to maximize total revenue (regardless of whether beef production increases or decreases at the industry level) is to increase his livestock numbers through profitable investments in range improvements or other means of increasing carrying capacity. Thus, indications are that cattle numbers will continue to show an upward trend.

\section{Literature Cited}

Agricultural Statistics. 1970. United States Government Printing Office: $627 \mathrm{p}$.

American National Cattleman's Association. 1968a. American National Cattleman's Association guidelines. Denver, Colorado.

American National Cattleman's Association. $1968 \mathrm{~b}$. Cattle Economics Report. 1:1-4. April, 1968. Denver, Colorado.

BreIMYer, H. F. 1961. Demand and price for meat. U.S. Dep. Agr. Tech. Bull. 1253. 78 p.

Cook, C. Wayne, and Ned Jeferies. 1963. Better distribution of cattle on mountain ranges. Utah Sci. 24:31-48.

GifFord, Claude W. 1968. What shifts in cattle numbers means to you. Farm Journal. 92:64A.

Hooper, Jack F., John P. Workman, Jim B. Grumbles, AND C. WAYNe Cook. 1969. Improved livestock distribution with fertilizer-a preliminary economics evaluation. J. Range Manage. 22:108-110.

Learn, Elmer W. 1956. Estimating demand for livestock products at the farm level. J. Farm. Econ. 28:1482-91.

Leftwich, Richard H. 1966. The Price System and Resource Allocation. Holt, Rinehart and Winston, Inc., New York. 3rd edition. $40 \mathrm{p}$.

Liebhafskx, H. H. 1963. The Nature of Price Theory. The Dorsey Press Inc., Homewood, Ill. 356 p.

Nielsen, Darwin B. 1967. Economics of range improvements. Utah Agr. Exp. Sta. Bull. 466. 49 p.

Richmond, SAmuel B. 1957. Statistical Analysis. The Ronald Press Company, New York. 2nd edition. $119 \mathrm{p}$.

Spencer, Milton H. 1968. Managerial Economics. Richard D. Darwin Inc., Homewood, Ill. 3rd edition. $401 \mathrm{p}$.

Tomek, William G. 1965. Changes in price elasticities of demand for beef, pork, and broilers. J. Farm Econ. 7:793-802.

UpGHURCH, M. L. 1967. Rangelands-challenge to the pocketbook. J. Range Manage. 20:284-287.

Working, Elmer J. 1927. What do statistical demand curves show? Quarterly J. Econ. 41:212-235.

Working, Elmer J. 1954. Demand for Meat. The University of Chicago Press. $136 \mathrm{p}$.

Workman, John P., AND JACK F. Hooper. 1968. Preliminary economic evaluation of cattle distribution practices on mountain rangelands. J. Range Manage. 21:301304. 